\title{
Strategies for adapting to hazards and environmental inequalities in coastal urban areas: what kind of resilience for these territories?
}

\author{
Nathalie Long ${ }^{1}$, Pierre Cornut ${ }^{2}$, and Virginia Kolb ${ }^{1}$ \\ ${ }^{1}$ LIENSs, La Rochelle université - CNRS, 17000 La Rochelle, France \\ ${ }^{2}$ Faculté d'architecture et d'urbanisme, Université de Mons, Mons, Belgium \\ Correspondence: Nathalie Long (nathalie.long@univ-lr.fr)
}

Received: 30 September 2020 - Discussion started: 13 November 2020

Accepted: 8 February 2021 - Published: 24 March 2021

\begin{abstract}
The ongoing phenomenon of climate change is leading to an upsurge in the number of extreme events. Territories must adapt to these modifications in order to protect their populations and the properties present in coastal areas. The adaptation of coastal areas also aims to make them more resilient to future events. In this article, we examine two strategies for adapting to coastal risks: holding the coastal line through hard constructions such as seawalls or ripraps and the managed retreat of activities and populations to a part of the territory not exposed to hazards. In France, these approaches are financed by a solidarity insurance system at the national level as well as local taxes. These solidarity systems aim to compensate the affected populations and finance implementation of the strategies chosen by local authorities. However, the French mainland coast generally attracts affluent residents, the price of land being higher than inland. This situation induces the presence of inequalities in these territories, inequalities which can be maintained or reinforced in the short and medium term when a defense strategy based on hard constructions is implemented. In such a trajectory, it appears that these territories would be less resilient in the long term because of the maintenance costs of the structures and the uncertainties relating to the hazards (submersion, rising sea levels, erosion). Conversely, with a managed-retreat strategy, inequalities would instead be done away with since property and populations would no longer be exposed to hazards, which would cost society less and would lead these territories towards greater resilience in the long term. Only one social group would be strongly impacted by this strategy in the short term when they are subjected to a managed retreat to another part of the territory.
\end{abstract}

\section{Introduction, state of the art and objectives}

Coastal territories are nowadays areas with high stakes, on both the social and economic levels. These attractive territories host most of the world's major megalopolises, with population densities higher than those of inland towns (Neumann et al., 2015). However, in the context of climate change, these same territories find themselves exposed to meteorological and marine hazards, such as marine submersions, coastal erosion or rising sea levels. Urban growth must therefore adapt to these new environmental conditions and respond to issues of sustainability, resilience and equity between different social groups (Hurlimann et al., 2014). Three main types of adaptation strategy are being implemented today with different social and environmental impacts (Williams et al., 2018): holding the coastal line through the construction of hard protective structures, the managed retreat of properties and infrastructure, or mitigation. The choice between either strategy is most often based on a cost-benefit approach and therefore depends on the value of assets and properties present in the territory (Cooper and McKenna, 2008; André et al., 2016). This approach favors a certain equity because it is based on economic metrics that allow monetary cost comparisons; on the other hand, it excludes all human and social considerations, such as the capacity to adapt at the individual level, attachment to a place and memory of the risk as well as the maintenance or reinforcement of inequalities (Boda, 2018; Füssel and Klein, 2006; Ramm et al., 2018).

This approach can also favor or disadvantage certain social groups. Many studies have shown that environmental policies have different impacts according to social group, generally disadvantaging the poorest, the most exposed to coastal risks and the most vulnerable from a social point of view (Wal- 
lace, 2012; Velez et al., 2018). Social justice, defined as a fair distribution of costs and benefits over the entire population, can be questioned here and supplemented by an environmental dimension, namely ecosystem protection (Cooper and McKenna, 2008; Dobson, 1999). In the same way, Eriksen et al. (2011) specify that an adaptation to climate change can only be deemed successful if it achieves social and environmental sustainability by factoring in both social justice and environmental integrity. Thus, the exposure of the poorest populations to climate change is often used as a pretext for implementing adaptation measures, but they are rarely evaluated according to this criterion and will not, in any case, alleviate either poverty or inequalities (Eriksen et al., 2011).

Coastal urban territories must therefore be studied as a system for taking into account both social and environmental dimensions as well as their interrelationships. Understood as a system, the coastline can then be approached according to the theory of resilience as an evolving system that is able to adapt to changes, in this case concerning the climate. According to Holling and Gunderson (2002), every system is in a dynamic of cycles which evolve at different spatial and temporal scales through different phases represented by the wellknown "figure eight" (Holling, 2001). By adopting the key principles of the theory of resilience (Holling et al., 2002) with regard to the characteristics of coastal urban territories, the observable changes are effectively either continuous or episodic, uniform or highly spatially variable, destabilizing or conversely a source of stability, which leads us to conclude that management policies must be tailored to these spaces, more with a view to ensuring the resilience than the stability of these spaces, endeavoring to maintain them in their current state (Walker et al., 2004; Curtin and Parker, 2014). Adaptation can be considered to be "a process of deliberate change in anticipation or in reaction to external stimuli or stress" (Nelson et al., 2007). Adaptation implies a human intervention through the establishment of policies that aim at a sustainable development of the territories based on an egalitarian and fair society (Klein et al., 2003). They must allow the development of new adaptive policy pathways (Rocle et al., 2020) while accepting a significant degree of uncertainty as to the future development of the system (Redman and Kinzig, 2003).

In this article, we examine the impacts in terms of the inequalities of two coastal-risk-management policies: holding the coastal line by building seawalls or ripraps and managed retreat. Broaching the matter through environmental inequalities (EIs) makes it possible to tackle, in parallel, social and environmental aspects as described previously by Eriksen et al. (2011), which the concept of social justice does not allow. In general terms, environmental inequalities are defined as intra- and inter-generational social inequalities partly determined by the state of the environment and partly by the way society is organized. Two approaches to inequality coexist: in the first approach, the definition is based on individuals' point of view, considering that inequalities do not exist as such but rather that they are felt by individuals. In this case, inequality is defined as "a difference that is perceived or experienced as unfair, as not ensuring the same opportunities for everyone" (Brunet et al., 1992). The second approach considers that inequality arises when there is an unequal distribution of goods among individuals within society. In this case, inequality exists when an individual or a population holds resources or has access to certain goods or services and to certain practices unlike others. This definition is based on the existence of a hierarchical scale common to the whole of society and on which the vectors of inequality are uniformly classified. This second approach is used here.

More specifically on the coast, inequalities arise when a social group is disproportionately affected by a risk compared to other social groups (Pye et al., 2008; Deldreve, 2015; Brulle and Pellow, 2006). Brulle and Pellow (2006) also add that environmental inequalities are products of society and its dynamics and, in coastal areas, result from the particular way in which this society is organized. Inequalities are thus defined in relation to others or to a benchmark which fully justifies their use to analyze the impacts of coastal-management strategies on the populations concerned and their living area. Inequalities also reflect a greater or lesser distance between the different social groups (Uslaner and Brown, 2005) and can compromise the expression of social solidarity (Durkheim, 1964), which, in crisis and post-crisis situations as during a natural disaster, can be problematic for finding a new state of equilibrium. Coastal-riskmanagement policies must not compromise this ability of territories to be resilient in a way which is both humane (less inequality for more solidarity and therefore sustainability of the social system) and environmental (protection of the environment and of its role as a buffer zone in the face of marine hazards).

In coastal urban areas, there are many inequalities (Kolb et al., 2014). Only three types of EI are discussed in this article because they are intrinsically linked to the management of coastal risks: inequalities in access to land, inequalities in exposure to risk and inequalities in access to the coastline perceived as an amenity (see Appendix A for the definition of each of these inequalities). Territorial inequalities through economic development and infrastructural services can also be present in coastal areas but are not directly linked to risk management. In the current context of increasing hazards, the question posed is whether the strategies for adapting to coastal risks more particularly will exacerbate or, on the contrary, alleviate the environmental inequalities already present in these territories and so influence their resilience. We propose to engage in this examination on two timescales: in the short term, through one-off actions carried out, and in the long term, taking into account their sustainability for future generations. In other words, are environmental changes and the societal response to them likely to increase or decrease environmental inequalities? The case of the northern part of Charente-Maritime (France) is taken as an example, even if 

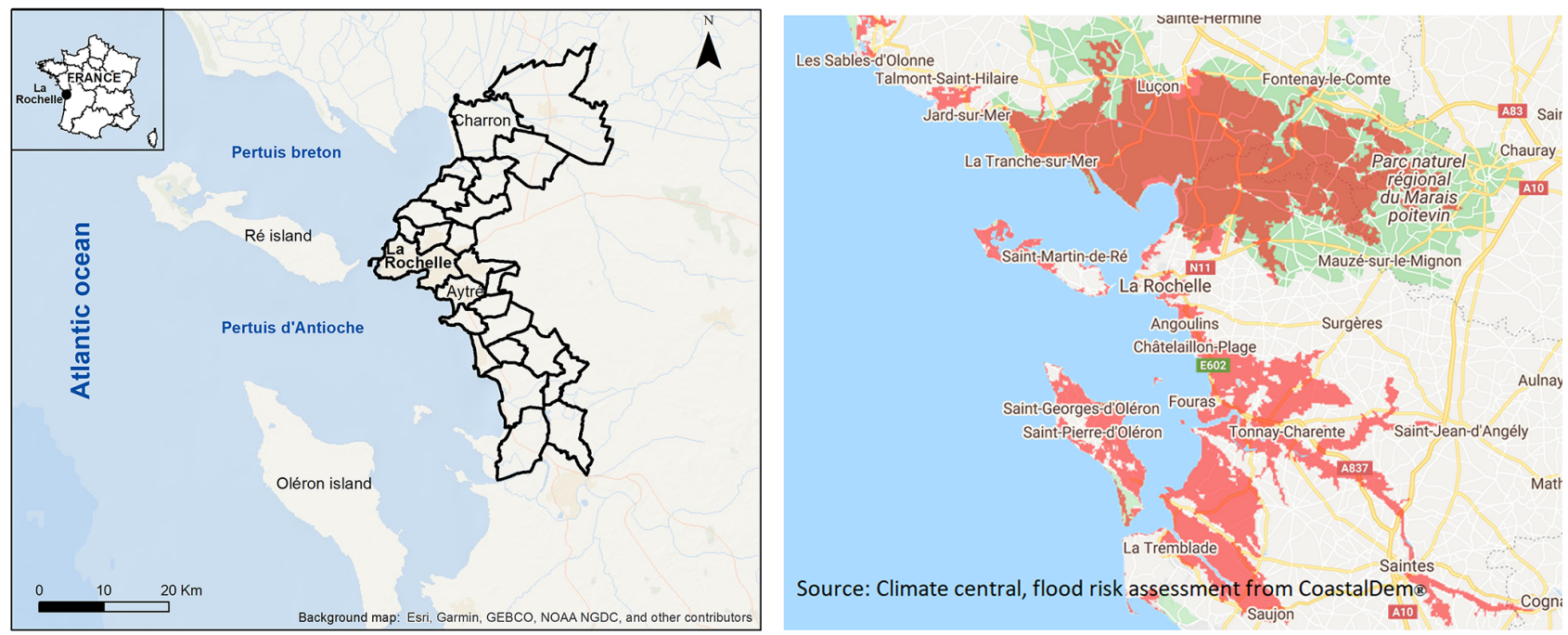

Figure 1. Left panel: the 25 coastal municipalities studied close to the city center of La Rochelle on the Atlantic coast (the black lines represent the municipal boundaries; Aytré and Charron are the main studied municipalities; source: IGN BDTopo ${ }^{\circledR}$ ). Right panel: flood risk assessment (in red: the land projected to be below annual flood level in 2050 ; the coastalDEM ${ }^{\circledR}$ does not take into account dikes or other hard defense structures).

the scope of this argument is intended to be more general. In the second part, we present the French context by describing the coastal-risk-management strategies and their mode of financing to establish the framework for our examination in order to engage with the methodological explanation in the third part. The results are presented in the fourth part and then discussed in the fifth part before concluding this article.

\section{The French context through the La Rochelle case study}

\subsection{Presentation of the study area}

During the Inegalitto project, we had the opportunity to study a coastal territory in the west of France, around La Rochelle. This territory includes the coastal municipalities and their neighboring municipalities in the agglomeration of La Rochelle, to which the municipality of Charron has been added to the north in order to preserve a certain geographical continuity on the scale of Pertuis Charentais (25 municipalities studied; Fig. 1). Located on the Atlantic coast, this area is fairly urbanized and attractive, with two seaside resorts, namely La Rochelle and Châtelaillon-Plage. La Rochelle is the main city, with nearly 76000 inhabitants. It also hosts the majority of jobs, infrastructures and amenities. The population density in the agglomeration of La Rochelle is the highest in the department, with 415 inhabitants per square kilometer, but features a very high spatial variability, with $50 \%$ of the population present in the city center. The coastal zone is somewhat characterized by an aging population, while the inland municipalities are fairly dynamic thanks to the ar- rival of families with young children. From a morphological and sedimentary point of view, the coast is firstly silty to the north, in the Baie de l'Aiguillon, then features cliffs north of La Rochelle, followed by a few sandy beaches, artificially maintained by regular refilling with sand for some, or beaches with pebbles or silt through to the south of the study area.

Charron, the second specific study site within the framework of the Inegalitto project, is located north of the Pertuis Breton. This municipality is characterized by a productive economy based on agriculture and shellfish farming. It has fewer than 2000 inhabitants but occupies a strategic position between two municipalities with employment areas: $\mathrm{La}$ Rochelle in the south and Luçon in the north, in the department of La Vendée. Here, the coast is fairly silty, making it less attractive for tourism but more natural.

This study area was strongly impacted during Storm Xynthia in February 2010. This storm generated a storm surge that reached its maximum in the center of the Bay of Biscay, with a maximum of $1.5 \mathrm{~m}$ (harbor of La Pallice, La Rochelle) in the same time as the high tide, resulting in a total water level of $8.01 \mathrm{~m}$ above marine chart datum in $\mathrm{La}$ Pallice (Bertin et al., 2012). Material damage was significant, and lives were lost. In addition to this type of extreme hazard, there is a slower hazard to be taken into consideration: the sea level rise. As part of the global change, there is a $\sim 3 \mathrm{~mm} \mathrm{yr}^{-1}$ sea level rise in the Bay of Biscay (Marcos et al., 2007; Dodet et al., 2019). Following the extreme event of Xynthia and in the context of global change, the legislation and its implementation were strengthened at the national level. The Inegalitto research project made it possible 
to question the management of coastal risks in France over the decade following this major event.

\subsection{Coastal-protection strategies and funding mechanisms at national and local level}

Faced with natural disasters, the French state has introduced original compensation schemes for damage suffered following a natural disaster based on solidarity at the national level first, then local since 2018. In terms of protection and prevention, three main strategies have been initiated in France and have different environmental and societal impacts (Williams et al., 2018). We are only covering two of these three strategies here.

i. Holding the coastal line by constructing hard defensive works such as seawalls or ripraps: this strategy makes it possible to protect the properties directly exposed to hazards and to keep them in place. These properties have a value that is greater than the cost of building a seawall. This strategy favors maintaining the territory and its population in its current structure and organization. It can, however, have a significant negative impact on the environment itself and its amenities: for example, for certain types of sandy coastline, the disappearance of the beach in the short and medium term.

ii. The managed retreat of the properties: this time, the assets have a lower value, and it is then decided to demolish them rather than keep them near the coast in an area exposed to hazards. This strategy leads to a spatial reconfiguration of the territories and a displacement of the population. The positive impact on the environment is also important, with a return to the naturalness of the coast. Portions of territory can thus be returned to the sea and play their role of buffer zone during storms. However, for the populations concerned, it can be more overwhelming from an emotional and organizational point of view, depending on the capabilities of the individuals (Sen, 1997).

To set up these risk management strategies, the so-called "Barnier law" in 1995 introduced various risk prevention plans, including PPRLs (coastal-risk-prevention plans) as of 1997 (and updated in 2011 following Storm Xynthia and the exceptional floods in the Var department, France). These plans aim to reduce the vulnerability of people and property by defining compulsory prevention, protection and safeguard measures and by establishing zoning to control construction in exposed areas. To implement these comprehensive measures at the local level, PAPIs (flood prevention and action programs) have been defined. Finally, to finance these actions, the Fund for the Prevention of Major Natural Risks, known as the "Barnier Fund", was also created by this law in 1995. This fund also makes it possible to finance or cofinance (i) expropriations or amicable acquisitions of property following a disaster and when the threat is still present, (ii) studies and construction work leading to a reduction in vulnerability or the compliance of structures, and (iii) information campaigns. The Barnier Fund is financed by a compulsory levy on the additional premium paid by all policyholders under the coverage against natural disasters: $12 \%$ on home insurance contracts and $6 \%$ on vehicle insurance contracts. This represents around EUR 200 million paid per year by insurance firms. This procedure, commonly called the Cat-Nat system (short for natural disasters in French), is based on national solidarity because the financing is organized on the basis of an additional premium paid by all holders of comprehensive insurance policies. But in the wake of the MAPTAM law (law on the modernization of territorial public action and the affirmation of metropolises) of 2014, relating to the modernization of territorial public action and the affirmation of metropolises, authority for GEMAPI (aquatic-environment management and flood prevention) has since 1 January 2018 been assigned to municipalities and their EPCIs (public inter-municipal cooperation establishments). Although the state, regions and departments were previously the main contracting authorities and co-financers of defense infrastructures, all of this is now managed at the local level. This decentralization of authority allows the EPCIs to levy a new tax, known as the GEMAPI tax, varying from one local authority to another and capped at EUR 40 per inhabitant. It is therefore also a solidarity mechanism but this time on a local scale (municipal and inter-municipal), which was recently put in place.

\section{Data and methods}

\subsection{Results from the Inegalitto project}

The main results of the Inegalitto project are presented in this section. They served as a basis for our reflections on the possible links between environmental inequalities and resilience of coastal territories. This article aims to produce an increase in generality rather than to present the results of the project themselves.

The Inegalitto project questioned the environmental inequalities produced by risk management policies in coastal urban areas. The chosen approach was mixed and based on both a quantitative and a qualitative study. The first part of this project consisted of mapping environmental inequalities using indexes to measure inequalities in access to natural and anthropogenic amenities, inequalities in exposure to natural and industrial risks, and inequalities on the economic level from several databases. As an example, the index of inequalities in exposure to risk is based on distribution of households in space and on areas at risk of submersion, flooding and erosion (more details in Long et al., 2019). These inequalities were then compared with social ones, defined by socio-demographic data at the household level from national statistical databases. Starting from the hypothesis that the 
most socially vulnerable populations are the most exposed to risks and have the least access to natural amenities, our results have shown that in the case of the La Rochelle agglomeration, these two hypotheses do not hold true in that the better-off populations may also be exposed to risks and find themselves some distance from natural amenities (Long et al., 2019). The explanation lies in the socio-spatial structure of the city of La Rochelle, which is superimposed on the coastal effect in the distribution of households over the whole of the agglomeration.

The second part of the project favored a qualitative approach. The surveys were carried out in 2017 in Aytré and in 2018 in Charron. The people interviewed were local politicians, associations and residents. The aim of the surveys was to analyze residents' representations of coastal risk, to address the issue of compensation for households exposed to coastal risk and to compare differential treatment between areas. The communes of Aytré and Charron have benefited from the construction of seawalls to protect the assets and populations from future marine submersions but have also experienced managed retreat, with the demolition of many residential houses and so the disappearance of part of the neighborhoods impacted by the flooding during Storm Xynthia. According to the surveys carried out, in Aytré, the population questioned seems to have grasped the fact that living near the coast remains a privilege and that the downside is being exposed to these risks. This risk has become banal in the sense that it is factored into their everyday life. The population does not deny it but tucks it away as an afterthought. The populations furthest from the coast in this town are however beginning to question why they have to pay (via the insurance premium and the GEMAPI tax) to protect those who persist in living in areas exposed to coastal risks. In Charron, the population is still scarred by the disaster following Storm Xynthia. The spontaneous solidarity which manifested itself immediately after the storm allowed the constitution of a still existing network of sociability, but today, part of this network is keen to move on and project a more positive image of the municipality. On the other hand, the interviews unanimously reveal a sense of injustice when it comes to the treatment of territories compared to other municipalities where the procedures and the work to ensure protection by hard structures were implemented much faster. Here it is inequality in the capacity to challenge public authorities that is often cited as well as an inequality of treatment between the territories.

\subsection{Method}

To assess the effects of the hazard as well as the choice of defense strategies and financing mechanisms regarding environmental inequalities, we have chosen to model the different situations as follows. According to the results of the quantitative study of the Inegalitto project, it emerges that it is important to know the status of households (owner or tenant) on the coastal strip to assess the impact of an adaptation strategy and the properties that can be demolished or maintained and protected. The consequences for the households concerned will then be of varying degrees of severity. In terms of financing these strategies, however, the status of the household is irrelevant; as seen above, each individual contributes indirectly (insurance premium and the GEMAPI tax) to the financing of these strategies. Based on these criteria, in the French context, three social groups are proposed: two groups at the municipal level (private owners living on the coast - POs - and other inhabitants of coastal municipalities - ICMs) and a final group dubbed inhabitants of non-coastal municipalities (INCMs). Subsequently, two time frames were considered: the short term, when defense structures are built or managed retreats carried out quickly after an event, and the long term by taking into account future generations from the three population categories. In the latter case, our working hypothesis is an identical continuation of the coastal-risk-management policy and its mode of financing, whatever the evolution of the hazard. Finally, we apply an adaptation strategy to these six cases ( 3 groups $\times 2$ time frames) either by maintaining the coastline through the construction of hard defense structures or through managed retreat, so obtaining 12 situations (Table 1).

For each of these situations, we evaluated, on the one hand, the costs borne by the populations and, on the other, the advantages obtained and the drawbacks suffered by these populations. This evaluation is of a qualitative nature, aiming above all to differentiate the situations of the three social groups identified. The methodology for evaluating the costs incurred is simply based on the application of the French financing and insurance law. Regarding the advantages obtained and the drawbacks suffered, we have defined a series of qualitative indicators based on the literature concerning EIs (Kolb et al., 2014) and on our knowledge of the field and our expertise acquired within the Inegalitto project. These indicators are therefore classified according to the main types of environmental inequalities (Table 2): economic or social access inequalities (indicator: economic and property values), access inequalities to environmental amenities (indicators: accessibility to the coast, environmental evolution of the coast), risk exposure inequalities (indicator: natural hazard exposure), and finally social and cultural inequalities (indicators: inhabitant feeling, sense of place, social cohesion). They cut across the economic, environmental and socio-cultural dimensions of resilience (Assarkhaniki et al., 2020) and form the basis of our resilience analysis.

These indicators are estimated for each of the 12 situations according to a simple qualitative scale: improvement or preservation (with a nuance depending on whether the populations show high concern or low concern), neutrality, degradation (with the same nuance). This level of assessment is given from our knowledge of the field and the interviews. For example, "inhabitant feeling" is easily estimated as positive for POs and ICMs in the case of seawall and negative in 
Table 1. Presentation of the 12 situations analyzed according to the strategy, the time frame and the population group.

\begin{tabular}{|c|c|c|c|c|c|c|}
\hline & \multicolumn{3}{|c|}{ Hold the coastal line (seawall) (HL) } & \multicolumn{3}{|c|}{ Managed retreat (MR) } \\
\hline $\begin{array}{l}\text { Short } \\
\text { term }\end{array}$ & $\begin{array}{c}\text { Private } \\
\text { owners } \\
\text { (POs) }\end{array}$ & $\begin{array}{l}\text { Other inhabitants of } \\
\text { coastal municipalities } \\
\text { (ICMs) }\end{array}$ & $\begin{array}{c}\text { Inhabitants of } \\
\text { non-coastal } \\
\text { municipalities (INCMs) }\end{array}$ & $\begin{array}{c}\text { Private } \\
\text { Owners } \\
\text { (POs) }\end{array}$ & $\begin{array}{l}\text { Other inhabitants of } \\
\text { coastal municipalities } \\
\text { (ICMs) }\end{array}$ & $\begin{array}{l}\text { Inhabitants of } \\
\text { non-coastal } \\
\text { municipalities } \\
\text { (INCMs) }\end{array}$ \\
\hline $\begin{array}{l}\text { Long } \\
\text { term }\end{array}$ & $\begin{array}{c}\text { Private } \\
\text { owners } \\
\text { (POs) }\end{array}$ & $\begin{array}{l}\text { Other inhabitants of } \\
\text { coastal municipalities } \\
\text { (ICMs) }\end{array}$ & $\begin{array}{c}\text { Inhabitants of } \\
\text { non-coastal } \\
\text { municipalities (INCMs) }\end{array}$ & $\begin{array}{c}\text { Private } \\
\text { Owners } \\
\text { (POs) }\end{array}$ & $\begin{array}{l}\text { Other inhabitants of } \\
\text { coastal municipalities } \\
\text { (ICMs) }\end{array}$ & $\begin{array}{l}\text { Inhabitants of } \\
\text { non-coastal } \\
\text { municipalities } \\
\text { (INCMs) }\end{array}$ \\
\hline
\end{tabular}

Table 2. Indicators of environmental inequalities and their definition.

\begin{tabular}{ll}
\hline Indicators & Definition \\
\hline Economic and property values & Refers to the economic value of a property \\
\hline Accessibility to the coast & $\begin{array}{l}\text { Represents the degree of physical accessibility of the coastline, made possible } \\
\text { or otherwise by various public access points for pedestrians or vehicles }\end{array}$ \\
\hline Environmental evolution of the coast & Defines how the geomorphology of the coastline will evolve over time \\
\hline Natural hazard exposure & $\begin{array}{l}\text { Concerns the exposure of people and property to coastal risks such as marine } \\
\text { submersion, erosion and rising sea levels }\end{array}$ \\
\hline Inhabitant feeling & Defines people's feelings and emotions \\
\hline Sense of place & Translates the relationship and attachment to the place of the population \\
\hline Social cohesion & Defines the links between people in a community or a group \\
\hline
\end{tabular}

the case of managed retreat: our interviews and media papers show it clearly.

For greater clarity, the qualitative assessment scale of the indicators is represented in the graph by different colors (Table 3 ). The boxes are colored blue, white or burgundy depending on whether the indicator shows an advantage, a neutral situation or a drawback, respectively. The intensity of the color is in certain cases reduced to show that the advantage or the drawback is less important, given the geographical distance of the populations considered.

\section{Results}

\subsection{Costs incurred by the strategies}

\subsection{1 "Hold the coastal line" strategy}

In the short term, the cost of the seawall or riprap concerns its construction. It is financed by the Barnier Fund, which applies to all French insurance policyholders. Individually, the POs, ICMs and INCMs (Table 1) contribute to the financing at the same level via their insurance contract. Collectively, in terms of the solidarity mechanism, there is a double trans-

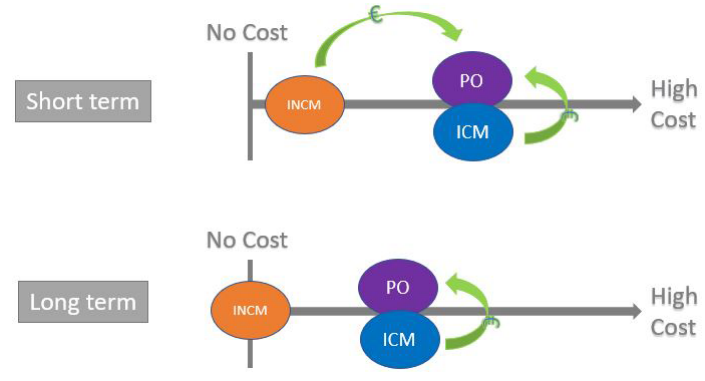

Figure 2. Evolution of cost for the "hold the coastal line" strategy.

fer of funding from the INCMs and the ICMs to the POs whose property is protected by the coastal defense (Fig. 2). They participate indirectly in financing the construction of the coastal defense without being directly affected by this risk.

In the long term, the cost of the coastal defense boils down to its maintenance, financed by the GEMAPI. Only the POs and the ICMs still bear a cost (less than for construction), and there is a simple transfer of solidarity from the ICMs to the POs. 
Table 3. Choice of colors for the qualitative representation of indicators.

\begin{tabular}{|c|c|c|c|c|}
\hline $\begin{array}{c}\text { Advantage } \\
\text { (high concern) }\end{array}$ & $\begin{array}{c}\text { Advantage } \\
\text { (low concern) }\end{array}$ & Neutral & $\begin{array}{c}\text { Drawback } \\
\text { (low concern) }\end{array}$ & $\begin{array}{c}\text { Drawback } \\
\text { (high concern) }\end{array}$ \\
\hline
\end{tabular}

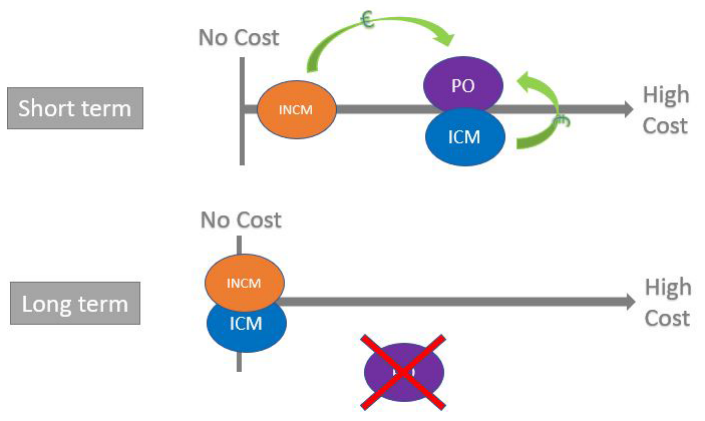

Figure 3. Evolution of cost for the "managed retreat" strategy.

\subsubsection{Managed-retreat strategy}

In the short term, the economic cost of demolition presents the same configuration as that of the coastal defense, both in terms of contribution levels and in solidarity transfers (Fig. 3). In the long term, however, the situation is radically different given the elimination of the assets: there are no more properties exposed because the POs have left; this cancels out the costs for the INCMs and ICMs.

\subsection{Advantages and drawbacks suffered}

We compare the two strategies here in the form of a table on the basis of the defined indicators. Interpreting the tables therefore makes it possible to easily summarize the advantages and drawbacks of the three population groups for the two time frames and the two adaptation strategies.

\subsubsection{In the short term}

According to Table 4, in the short term and according to a coastal-maintenance strategy, for all the indicators, the POs and ICMs see their advantages preserved, whether in terms of the value of their property or their well-being, among other factors. French citizens are barely concerned except for accessibility to the coast as a tourist destination. On the other hand, for the managed-retreat strategy, the POs are somewhat disadvantaged, with a loss of their property and their living space and being displaced away from the coast, although, on the other hand, they become less exposed to coastal risks or even not exposed at all. For the ICMs, only social type indicators indicate a loss because these population movements cause a loss of social cohesion for the affected territory. Economic indicators or those linked to coastal amenities are more positive for populations who can once again benefit from a coast that has become more natural again. Finally, we can hypothesize that the further we move away from the coastal regions, the less the populations are affected by the changes in these territories.

\subsubsection{In the long term}

In the long term, the POs enjoy as many advantages as in the short term in the event of protection by coastal defenses: their homes and living areas are maintained over time, and they continue to benefit from their property while being protected from coastal risks. In the event of managed retreat, however, the POs no longer exist (the properties having been demolished), and the ICMs benefit from a coast, which regains its status as a common good accessible to all (Table 5).

\subsection{Summary of results}

The summary of the results is presented by a schematic representation: each social group is positioned according to the costs borne on the horizontal axis and according to the advantages or drawbacks on the vertical axis (Fig. 4). The main conclusions that emerge from observation of the graphs are as follows.

i. In the short term, the three population groups are still required to make a financial contribution by paying the additional premium via their home and/or vehicle insurance contracts, which shores up the Barnier Fund. However, the consequences of these strategies are rather favorable to the POs and to a lesser extent to the ICMs in the case of protection by a hard structure but are largely unfavorable to the POs and rather favorable to the ICMs (except on social aspects) in the case of a managed retreat.

ii. In the long term, however, as we made the assumption of no change in the insurance system, the additional insurance premium remains compulsory; the three population groups thus continue to contribute indirectly to the Barnier Fund. Only the GEMAPI tax is to be taken into consideration for the ICMs, assuming that the POs who had to move have become either ICMs or INCMs. If there are no coastal defenses to maintain and a reduction in or even the elimination of assets to protect, we can then assume that the GEMAPI tax will be revised downwards by the EPCIs. The impacts are neutral or thereabouts for the INCMs and positive for the ICMs. 
Table 4. Short-term comparative advantages and drawbacks (* artificialization; ${ }^{* *}$ renaturation).

\begin{tabular}{|c|c|c|c|c|c|c|}
\hline \multirow[b]{2}{*}{$\begin{array}{l}\text { Adaptation } \\
\text { strategies } \\
\text { and social } \\
\text { groups } \\
\text { Which } \\
\text { Indicators }\end{array}$} & \multicolumn{3}{|c|}{ Hold the coastal line (seawall) } & \multicolumn{3}{|c|}{ Managed retreat } \\
\hline & $\begin{array}{l}\text { Private owners } \\
\text { (POs) }\end{array}$ & $\begin{array}{c}\text { Other } \\
\text { inhabitants of } \\
\text { coastal } \\
\text { municipalities } \\
\text { (ICMs) }\end{array}$ & $\begin{array}{l}\text { Inhabitants of } \\
\text { non-coastal } \\
\text { municipalities } \\
\text { (INCMs) }\end{array}$ & $\begin{array}{c}\text { Private } \\
\text { owners (POs) }\end{array}$ & $\begin{array}{c}\text { Other } \\
\text { inhabitants of } \\
\text { coastal } \\
\text { municipalities } \\
\text { (ICMs) }\end{array}$ & $\begin{array}{l}\text { Inhabitants of } \\
\text { non-coastal } \\
\text { municipalities } \\
\text { (INCMs) }\end{array}$ \\
\hline $\begin{array}{c}\text { Economic and } \\
\text { property } \\
\text { values }\end{array}$ & Preserved & Preserved & Neutral & $\begin{array}{l}\text { Loss of the } \\
\text { real property } \\
\text { but financial } \\
\text { compensation }\end{array}$ & Preserved & Neutral \\
\hline $\begin{array}{c}\text { Accessibility to } \\
\text { the coast }\end{array}$ & Preserved & Preserved & $\begin{array}{c}\text { Preserved } \\
\text { (low concern) }\end{array}$ & Decrease & Preserved & $\begin{array}{c}\text { Preserved } \\
\text { (low concern) }\end{array}$ \\
\hline $\begin{array}{c}\text { Environmental } \\
\text { evolution of } \\
\text { the coast }\end{array}$ & Art.* & Art.* & $\begin{array}{l}\text { Art.* (low } \\
\text { concern) }\end{array}$ & Renat*** & Renat** & $\begin{array}{c}\text { Renat** } \\
\text { (low concern) }\end{array}$ \\
\hline $\begin{array}{l}\text { Natural } \\
\text { hazard } \\
\text { exposure }\end{array}$ & $\begin{array}{l}\text { Protection of } \\
\text { buildings and } \\
\text { inhabitants and } \\
\text { lower exposure }\end{array}$ & $\begin{array}{l}\text { Protection of } \\
\text { territory and } \\
\text { lower exposure }\end{array}$ & $\begin{array}{l}\text { Protection of } \\
\text { territory (low } \\
\text { concern) }\end{array}$ & Decrease & Decrease & $\begin{array}{l}\text { Neutral (no } \\
\text { concern) }\end{array}$ \\
\hline $\begin{array}{c}\text { Inhabitant } \\
\text { feeling }\end{array}$ & Well-being & Well-being & Neutral & $\begin{array}{c}\text { Anxiety/ } \\
\text { stress linked } \\
\text { to relocation }\end{array}$ & Empathy & $\begin{array}{c}\text { Empathy (low } \\
\text { concern) }\end{array}$ \\
\hline Sense of place & Preserved & Preserved & Neutral & Total loss & $\begin{array}{l}\text { Decrease } \\
\text { (Indirect } \\
\text { concern) }\end{array}$ & Neutral \\
\hline Social cohesion & Preserved & Preserved & $\begin{array}{c}\text { Preserved } \\
\text { (low concern) }\end{array}$ & Decrease & Decrease & Neutral \\
\hline
\end{tabular}

iii. Solidarity transfers to POs are present in the event of the construction of a hard coastal defense as in the event of managed retreat, but they persist in the long term in the first case.

iv. In the short as in the long term, the advantages for the POs are much greater in the case of the construction of a hard coastal defense than in the event of managed retreat.

In terms of inequalities, we can deduce that inequalities in access to land are maintained on the coastal territory in the case of the implementation of a protection strategy by the construction of a hard coastal defense. On the other hand, they vanish in the case of a managed retreat following the demolition of these properties (Table 6) and can possibly appear in other parts of the territory. The spatial variability in land prices is in this case smoothed out over the short term as over the long term according to a land-sea gradient.

The unequal access to the coast as an amenity in the event of the construction of a short-term coastal defense is either maintained if the structure is inaccessible (privatization of the coast) or possibly reduced if the structure becomes a place to walk. However, in the long term and even in the medium term, this amenity (especially if it is a beach) may end up disappearing under the impact of the waves, which will lead to erosion of the coast. In the case of a managed retreat followed by renaturation of the coastline, this inequality should be eliminated, the coastline fully resuming its status 
Table 5. Long-term comparative advantages and drawbacks (*artificialization; ${ }^{* *}$ renaturation).

\begin{tabular}{|c|c|c|c|c|c|c|}
\hline \multirow[b]{2}{*}{$\begin{array}{l}\begin{array}{r}\text { Adaptation } \\
\text { strategies } \\
\text { and social } \\
\text { groups }\end{array} \\
\text { Which } \\
\text { Indicators }\end{array}$} & \multicolumn{3}{|c|}{ Hold the coastal line (seawall) } & \multicolumn{3}{|c|}{ Managed retreat } \\
\hline & $\begin{array}{l}\text { Private owners } \\
\text { (POs) }\end{array}$ & $\begin{array}{c}\text { Other } \\
\text { inhabitants of } \\
\text { coastal } \\
\text { municipalities } \\
\text { (ICMs) }\end{array}$ & $\begin{array}{l}\text { Inhabitants of } \\
\text { non-coastal } \\
\text { municipalities } \\
\text { (INCMs) }\end{array}$ & $\begin{array}{l}\text { Private owners } \\
\text { (POs) }\end{array}$ & $\begin{array}{l}\text { Other inhabitants of } \\
\text { coastal } \\
\text { municipalities } \\
\text { (ICMs) }\end{array}$ & $\begin{array}{l}\text { Inhabitants of non- } \\
\text { coastal } \\
\text { municipalities } \\
\text { (INCMs) }\end{array}$ \\
\hline $\begin{array}{l}\text { Economic and } \\
\text { property values }\end{array}$ & Preserved & Preserved & Neutral & & Preserved & Neutral \\
\hline $\begin{array}{c}\text { Accessibility to } \\
\text { the coast }\end{array}$ & Preserved & Preserved & $\begin{array}{l}\text { Preserved (low } \\
\text { concern) }\end{array}$ & & Preserved & $\begin{array}{l}\text { Preserved (low } \\
\text { concern) }\end{array}$ \\
\hline $\begin{array}{c}\text { Environmental } \\
\text { evolution of the } \\
\text { coast }\end{array}$ & $\begin{array}{c}\text { Art* and } \\
\text { possible loss of } \\
\text { amenity }\end{array}$ & $\begin{array}{c}\text { Art* and } \\
\text { possible loss of } \\
\text { amenity }\end{array}$ & $\begin{array}{l}\text { Art.* (low } \\
\text { concern) }\end{array}$ & & Renat.* & $\begin{array}{c}\text { Renat.* } \\
\text { (low concern) }\end{array}$ \\
\hline $\begin{array}{c}\text { Natural hazard } \\
\text { exposure }\end{array}$ & $\begin{array}{l}\text { Protection of } \\
\text { buildings and } \\
\text { inhabitants and } \\
\text { lower exposure }\end{array}$ & $\begin{array}{l}\text { Protection of } \\
\text { territory and } \\
\text { lower exposure }\end{array}$ & $\begin{array}{l}\text { Protection of } \\
\text { territory (low } \\
\text { concern) }\end{array}$ & & Lower exposure & $\begin{array}{l}\text { Neutral (not } \\
\text { concerned) }\end{array}$ \\
\hline $\begin{array}{c}\text { Inhabitant } \\
\text { feeling }\end{array}$ & Well-being & Well-being & Neutral & & Well-being & Neutral \\
\hline Sense of place & Preserved & Preserved & Neutral & & Preserved & Neutral \\
\hline Social cohesion & Preserved & Preserved & $\begin{array}{l}\text { Preserved (low } \\
\text { concern) }\end{array}$ & & Preserved & Neutral \\
\hline
\end{tabular}

as a common good and the beach continuing to exist or evolving towards a naturally resilient system.

On the other hand, the inequality of exposure to risks is greatly reduced during the construction of a coastal defense. Even if a risk remains, it can again increase in the long term if the structure is not sufficiently maintained. It becomes nonexistent in the case of a managed retreat because no human or structural assets are then exposed to the hazards.

Finally, the existing social inequalities are maintained when a coastal defense is built; moreover, a managed retreat leads to a population movement, which can destabilize a territory through a loss of social cohesion. However, in the long term, a new social cohesion can also be built.

In terms of resilience, the results are more clear-cut: in either environmental or social matters, demolition is surely more resilient in the long term. First, seawalls are only a short-term strategy given the century timescale of the sea level rise. The coastline is fixed and has no possibility of natural evolution or coping with global change, which is contrary to the definition of a resilient system. Second, social cohesion in the case of demolition will be renewed in the long term, especially with the past adaptation strategy in the mind of the local population. It is then essential to propose the adaptation strategy that will best preserve social cohesion because it is the guarantor of spontaneous solidarity following the occurrence of an extreme event. This solidarity makes it possible to define this society as more resilient because it is able to better cope and adapt.

\section{Discussion and conclusion}

The qualitative approach set out makes it possible to outline the effect of coastal risks and adaptation strategies on the EIs of the territory considered. Whatever the time frame, owners 


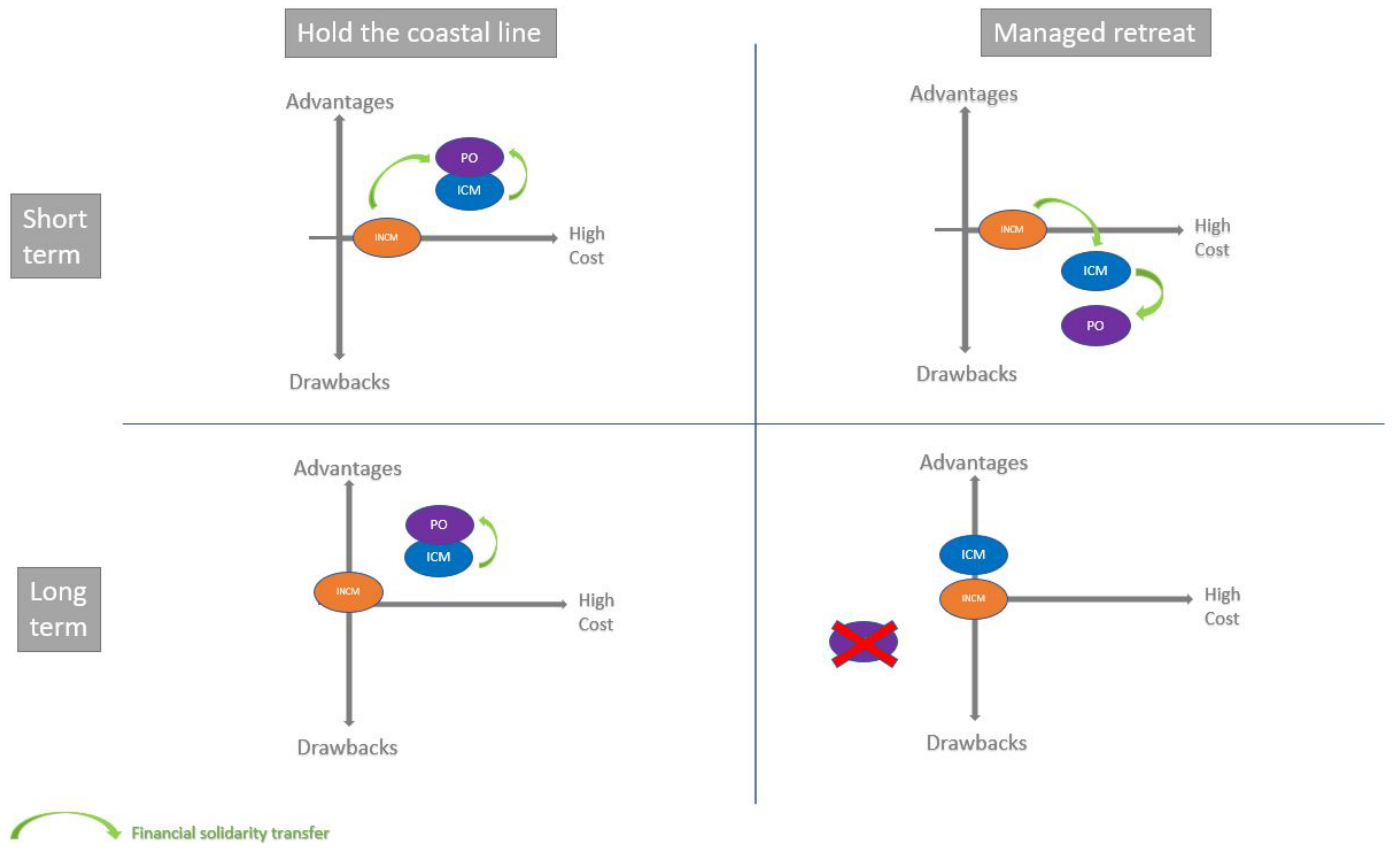

Figure 4. Evolution of cost and comparative advantages and drawbacks in the short and long term.

Table 6. Evolution of environmental inequalities.

\begin{tabular}{|c|c|c|c|c|}
\hline \multirow{2}{*}{$\begin{array}{l}\text { Adaptation strategies } \\
\text { and short/long } \\
\text { term } \\
\text { Envir onmental } \\
\text { inequalities }\end{array}$} & \multicolumn{2}{|c|}{ Hold the coastal line } & \multicolumn{2}{|c|}{ Managed retreat } \\
\hline & Short term & Long term & Short term & Long term \\
\hline $\begin{array}{c}\text { Unequal access to } \\
\text { land }\end{array}$ & \multicolumn{2}{|c|}{ Maintained } & \multicolumn{2}{|c|}{ Removed } \\
\hline $\begin{array}{l}\text { Unequal access to the } \\
\text { coast as an amenity }\end{array}$ & $\begin{array}{l}\text { Maintained or } \\
\text { reduced }\end{array}$ & Reinforced & \multicolumn{2}{|c|}{ Removed } \\
\hline $\begin{array}{c}\text { Unequal exposure to } \\
\text { risks }\end{array}$ & Scaled down & May increase again & \multicolumn{2}{|c|}{ Removed } \\
\hline $\begin{array}{l}\text { Existing social } \\
\text { inequalities }\end{array}$ & \multicolumn{2}{|c|}{ Maintained } & Reinforced & $\begin{array}{c}\text { Possibly reduced in a } \\
\text { new managed retreat } \\
\text { context }\end{array}$ \\
\hline
\end{tabular}

of properties on the coast have a clear advantage in the case of protection by coastal defenses, and these hard structures cost the local authority more than demolition, given the longterm maintenance required. Do the strategies as well as their mode of financing by the Barnier Fund and then maintenance via the GEMAPI nevertheless reinforce the EIs? This would clearly be the case if there were an initial inequality between the owners of property on the coast and the rest of the inhabitants of France. In this specific case, the owners of prop- erty on the coast, who may be labeled as a privileged population, benefit from protective measures by the construction of a coastal defense, financed by solidarity transfers, allowing them to retain their property and lifestyles, so maintaining or strengthening their privileged position. In the event of demolition, on the other hand, this so-called favored population loses its initial advantage (but is nevertheless compensated), which leads to a reduction in (or a displacement of) EIs, in 
addition to the benefit of better security of the coast and its renaturation.

Is this initial inequality real? Based on the statistical databases available in France, it is difficult to validate this hypothesis of the favored social position of coastal-property owners (Long et al., 2019). Income levels are not known at the household level, so it is impossible to demonstrate a spatial correlation between high income and the presence of these households on the coast.

On the other hand, beyond the statistical demonstration, the Barnier law nevertheless causes a reinforcement of the EIs. In fact, the choice of the strategy of adaptation to coastal risks is linked to an economic calculation of the cost-benefit type. In the event of high land prices, the costs of demolition, including expropriation and compensation for owners, are such that the building of hard structures of defense will be preferred for financial reasons. Thus, in the municipality of Charron, where the average price of property per square meter is on average EUR 1800, 180 houses were demolished following Storm Xynthia, while on the Ile de Ré, where the price of land varies between EUR 5000 and EUR $7300 \mathrm{~m}^{-2}$ on average, a seawall construction plan was preferred for the island (source: http://www.meilleursagents.com, last access: 27 August 2020). And therefore, the richer the owners (generally the case when the land prices are high), the more likely they are to be protected by a seawall instead of being subjected to managed retreat. In this case, for the same cost incurred, the mode of protection benefits them to a large degree, including in the long term (left-hand side of Fig. 4). In the event of low land prices, demolition is less expensive than the construction of a coastal defense and will therefore probably be chosen to the detriment of the owners, certainly less wealthy, who will be subjected to managed retreat (righthand side of Fig. 4). There is therefore a reinforcement of environmental inequalities and, in particular, inequality in the treatment of territories, often suffered by the populations. Following this argument, the conclusion is however totally opposite in the matter of resilience: poorer territories should become more resilient than richer ones in the long term.

However, it should be noted that over the long term, these conclusions can be qualified. We have in fact taken as a hypothesis an unchanged policy whatever the evolution of the hazard. This being largely uncertain, nothing indicates that the current protection measures will be sufficient and if, therefore, adaptation and financing policies will not have to be reviewed. It would thus seem that, still in the long term, managed retreat leads the territories to be more resilient than when the choice to hold the coastal line is made; obviously, a new state of equilibrium has been reached in the system, but it appears to be more precarious and more fragile in the long term. The coastline is a system in perpetual evolution; we can then assume that this strategy will be costly and unsustainable in the long term and that a new trajectory will have to be adopted.
In a context of climate change, with an increase in extreme events and rising sea levels, the French insurance system could be called into question fairly soon, not to mention the functioning of the Barnier Fund. Indeed, although EUR 200 million $\mathrm{yr}^{-1}$ of receipts currently permits compensation for the people and property affected, what will happen in the future if disasters show a tendency to increase in number and intensity? Should the percentage deducted from the Cat-Nat surcharge be raised? Will the insurance policyholders always agree to pay for the inhabitants of coastal areas? Should we fear a system where insurers will no longer insure properties and people in risk areas or where only the richest will be able to pay very high premiums to continue living in these territories? Will the coast continue to be attractive? A study conducted in southern Florida by Theurer et al. (2018), for example, has shown following surveys that, faced with the increase in sea level, it is the youngest owners (under 45) who are most inclined to move fairly early on, but in contrast middle-income earners are the least willing to move. However, along our coasts, the population tends to be aging.

The choices between these different strategies for adapting to coastal risks are not simple, and another parameter must be taken into account: that of path dependency (Lawrence et al., 2018). Our methodology, based on qualitative and quantitative indicators, has been inspired by our research experience in the Inegalitto project. Although we took into account the coast typology and the actors' behaviors, acknowledging the fact that "space matters", path dependency is still questionable. We intend in the coming months to test our methodology on other coastal areas, first in the same juridic French context, second in other countries. The territories each have their own history, and some have historically chosen to gradually claw back from the sea land that has become rich and fertile for agriculture (polders). Today, this land is found below sea level, protected by a seawall. How then is it possible to go back in time and have people accept that this land be returned to the sea and serve as a buffer zone, welcoming seawater during submersions to prevent inland flooding? The question of social and environmental justice arises here and could be considered to be a criterion as important as the economic one for the future choices to be made in terms of adaptation of coastal territories. 


\section{Appendix A: Types of inequalities considered in the article}

\section{A1 Inequality in access to land}

This inequality represents accessibility to land, that is to say the possibility that a household has to buy or rent property throughout its living area. Depending on certain factors, such as in our case the proximity of an attractive coastline, prices vary greatly, with a decrease in the price per square meter from the coast to the interior. Certain parts of the territory, therefore close to the coast, are inaccessible in residential terms for certain social categories.

\section{A2 Inequality in exposure to coastal risks}

Only exposures to hazards from the sea such as submersion, erosion or rising sea levels are taken into account. Exposure to these risks is uneven in the territory and depends on the morphology of the coast (beach or cliff; silt, sand or pebbles; etc.) and on its evolution over time. Some sites may become exposed to hazards over time for natural or man-made reasons.

\section{A3 Inequality in access to the coast perceived as an amenity}

The coastline is understood here as a natural amenity, that is to say as "local attributes that provide a set of benefits to people (especially climatic, aesthetic and recreational benefits), $[\ldots]$ a contribution to the overall well-being or quality of life of the residents in a location, [...] as local characteristics generating attractiveness" (Schaeffer and Dissart, 2018). It is recognized as a common good of humanity, but sometimes because of private developments on the coast, its access is no longer possible. We are also witnessing the privatization of portions of the coast for economic activities, access to which will be reserved for people paying an admission fee.

\section{A4 Social inequality}

In our study, social inequality is only measured through the level of household income. 
Data availability. No data sets were used in this article.

Author contributions. All three authors have contributed to the conceptualization, the methodology, the visualization and the writing of the paper.

Competing interests. The authors declare that they have no conflict of interest.

Special issue statement. This article is part of the special issue "Resilience to risks in built environments". It is a result of the EGU General Assembly 2019, Vienna, Austria, 7-12 April 2019.

Acknowledgements. This work was supported by the Fondation de France.

Financial support. This research has been supported by the Fondation de France (grant no. 150884).

Review statement. This paper was edited by Bruno Barroca and reviewed by two anonymous referees.

\section{References}

André, C., Boulet, D., Rey-Valette, H., and Rulleau, B.: Protection by hard defence structures or relocation of assets exposed to coastal risks: contributions and drawbacks of cost-benefit analysis for long-term adaptation choices to climate change, Ocean Coast. Manage., 134, 173-182, https://doi.org/10.1016/j.ocecoaman.2016.10.003, 2016.

Assarkhaniki, Z., Rajabifard, A., and Sabri, S.: The conceptualisation of resilience dimensions and comprehensive quantification of the associated indicators: a systematic approach, Int. J. Disast. Risk Reduct., 51, 101840, https://doi.org/10.1016/j.ijdrr.2020.101840, 2020.

Bertin, X., Bruneau, N., Breilh, J. F., Fortunato, A. B., and Karpytchev, M.: Importance of wave age and resonance in storm surges: the cas Xynthia, Bay of Biscay, Ocean Model., 42, 16-30, https://doi.org/10.1016/j.ocemod.2011.11.001, 2012.

Boda, C. S.: From economic choice to social choice in coastal management: a critical assessment of the use of cost-benefit analysis in the evaluation of an erosion control project in Flagler County, Florida, U. S. A., Ocean Coast. Manage., 162, 85-99, https://doi.org/10.1016/j.ocecoaman.2017.09.017, 2018.

Brulle, R. J. and Pellow, D. N.: Environmental justice: human health and environmental inequalities, Annu. Rev. Publ. Health, 27, 103-124, https://doi.org/10.1146/annurev.publhealth.27.021405.102124, 2006.
Brunet, R., Ferras, R., and Théry, H.: Les mots de la géographie: dictionnaire critique, Ed. Reclus-La Documentation Française, Montpellier, Paris, 470 pp., 1992.

Cooper, J. A. G. and McKenna, J. M.: Social justice in coastal erosion management: the temporal and spatial dimensions, Geoforum, 39, 294-306, https://doi.org/10.1016/j.geoforum.2007.06.007, 2008.

Curtin, C. G. and Parker, J. P.: Foundations of resilience thinking, Conserv. Biol., 28, 912-923, https://doi.org/10.1111/cobi.12321, 2014.

Deldreve, V.: Pour une sociologie des inégalités environnementales, Collection Ecopolis, Vol. 24, Peter Lang, Bruxelles, 2015.

Dobson, A.: Fairness and futurity: essays on environmental sustainability and social justice, Oxford University Press, Oxford, 344 pp. 1999.

Dodet, G., Bertin, X., Bouchette, F., Gravelle, M., Testut, L., and Wöppelmann, G.: Characterization of se-level variations along the metropolitan coasts of Frnace : waves, tides storm surges and long-term changes, J. Coast. Res., 88, 10-24, https://doi.org/10.2112/SI88-003.1, 2019.

Durkheim, E.: The Division of Labour in Society, Free Press, New York, USA, 439 pp., 1964.

Eriksen, S. Aldunce, P., Bahinipati, C. S., D’Almeida Martins, R., Molefe, J. I., Nhemachema, C., O'Brien, K., Olorunfemi, F., Park, J., Sygna, L., and Ulsrud, K.: When not every response to climate change is a good one: Identifying principles for sustainable adaptation, Clim. Dev., 3, 7-20, https://doi.org/10.3763/cdev.2010.0060, 2011.

Füssel, H. M. and Klein, R. J. T.: Climate change vulnerability assessments: an evolution of conceptual thinking, Climatic Change, 75, 310-329, https://doi.org/10.1007/s10584-006-03293, 2006.

Holling, C. S.: Understanding the complexity of economic, ecological and social systems, Ecosystems, 4, 390-405, https://doi.org/10.1007/s10021-001-0101-5, 2001.

Holling, C. S. and Gunderson, L. H.: Resilience and adaptive cycles, in: Panarchy: understanding transformations in human and natural systems, edited by: Gunderson, L. H. and Holling, C. S., Island Press, Washington, USA, 25-62, 2002.

Holling, C. S., Gunderson, L. H., and Ludwig, D.: Inquest of a theory of adaptive change, in: Panarchy: understanding transformations in human and natural systems, edited by: Gunderson, L. H. and Holling, C. S., Island Press, Washington, USA, 3-24, 2002.

Hurlimann, A., Barnett, J., Fincher, R., Osbaldiston, N., Mortreux, C., and Graham, S.: Urban planning and sustainable adaptation to sea-level rise, Landscape Urban Plan., 126, 84-93, https://doi.org/10.1016/j.landurbplan.2013.12.013, 2014.

Klein, R. J. T., Nicholls, R. J., and Thomalla, T.: Resilience to natural hazards: how useful is this concept?, Environ. Hazards, 5 , 35-45, https://doi.org/10.1016/j.hazards.2004.02.001, 2003.

Kolb, V., Long, N., and Marty, P.: Is the coast a vector of socioenvironmental inequalities in coastal urban areas?, in: Proceeding of the CUI'14 - Contemporary Urban Issues conference: Rethinking the informality, 13-15 Novembre 2014, Istanbul, Turquie, 236-251, 2014.

Lawrence, J., Bell, R., Blackett, P., Stephens, S., and Allan, S.: National guidance for adapting to coastal hazards and sea-level rise: anticipating change, when and how 
to change pathway, Environ. Sci. Policy, 82, 100-107, https://doi.org/10.1016/j.envsci.2018.01.012, 2018.

Long, N., Cornut, P., and Kolb, V.: Environmental inequalities on the coast of North Charente-Maritime department in exposure hazards, in: Proceeding of the ICE Coastal Management conference, 24-26 September, La Rochelle, France, 10 pp., 2019.

Marcos, M., Wöppelmann, G., Bosch, W., and Savcenko, R.: Decadal se level trends in the Bay of Biscay from tide gauges, GPS and TOPEX, J. Mar. Syst., 68, 529-536, https://doi.org/10.1016/j.jmarsys.2007.02.006, 2007.

Nelson, D., Adger, W. N., and Brown, K.: Adaptation to environmental change: contributions of a resilience framework, Annu. Rev. Environ. Resour., 32, 395-419, https://doi.org/10.1146/annurev.energy.32.051807.090348, 2007.

Neumann, B., Vafeidis, A. T., Zimmermann, J., and Nicholls, R. J.: Future coastal population growth land exposure to sea-level rise and coastal flooding - A global assessment, PLoS ONE, 10, e0118571, https://doi.org/10.1371/journal.pone.0118571, 2015.

Pye, S., Skinner, I., Meyer-Ohlendorf, N., Leipprand, A., Lucas, K., and Salmons, R.: Addressing the social dimensions of environmental policy - A study on the linkages between environmental and social sustainability in Europe, European Commission, Directorate-General "Employment, Social Affairs and Equal Opportunities”, Brussels, 50 pp., 2008.

Ramm, T. D., Watson, C. S., and White, C. J.: Strategic adaptation pathway planning to manage sea-level rise and changing coastal flood risk, Environ. Sci. Policy, 87, 92-101, https://doi.org/10.1016/j.envsci.2018.06.001, 2018.

Redman, C. L. and Kinzig, A. P.: Resilience of past landscapes: resilience theory, society, and the Longue durée, Conserv. Ecol., 7, 14, 2003
Rocle, N., Rey-Valette, H., Bertrand, F., Bécu, N., Long, N., Bazart, C., Vye, D., Meur-Ferec, C., Beck, E., Almaric, M., and Lautrédou-Audouy, N.: Paving the way to coastal adaptation pathways: an interdisciplinary approach based on territorial archetypes, Environ. Sci. Policy, 110, 34-45, https://doi.org/10.1016/j.envsci.2020.05.003, 2020.

Schaeffer, Y. and Dissart, J. C.: Natural and environmental amenities: a review of definitions, measures and issues, Ecol. Econ., 146, 475-496, https://doi.org/10.1016/j.ecolecon.2017.12.001, 2018.

Sen, A.: Editorial: Human capital and human capability, World Dev., 25, 1959-1961, 1997.

Theurer, G., Broad, K., and Meyer, R.: Using simulations to forecast homeowner response to sea level rise in South Florida: will stay or will they go?, Global Environ. Change, 48, 108-118, https://doi.org/10.1016/j.gloenvcha.2017.10.008, 2018.

Uslaner, E. M. and Brown, M.: Inequality, Trust, and Civic Engagement, Am. Polit. Res., 33, 868-894, https://doi.org/10.1177/1532673X04271903, 2005.

Velez, J. M. M., Garcia, S. B., and Tenorio, A. E.: Policies in coastal wetlands: key challenges, Environ. Sci. Policy, 88, 7282, https://doi.org/10.1016/j.envsci.2018.06.016, 2018.

Walker, B., Holling, C. S., Carpenter, S. R., and Kinzig, A.: Resilience, adaptability and transformability in social-ecological systems, Ecol. Soc., 9, 5, 2004.

Wallace, D. J.: Policy and management hazards along the Upper Texas coast, Ocean Coast. Manage., 59, 77-82, https://doi.org/10.1016/j.ocecoaman.2011.12.021, 2012.

Williams, A. T., Rangel-Buitrago, N., Pranzinid, E., and Anfuso, G.: The management of coastal erosion, Ocean Coast. Manage., 156 4-20, https://doi.org/10.1016/j.ocecoaman.2017.03.022, 2018. 